Research Article

\title{
Cytotoxic Activity of Zinc Oxide Nanoparticles Using Zingiber officinale Rhizome Extracts against Leukemia (K562) Cell Line
}

\author{
Sayantani Pal ${ }^{1,2}$, Tapas Kumar Pal' ${ }^{2}$, Shila Elizabeth Besra ${ }^{1 *}$ \\ 1.Central Instrumentation Facility and Cancer Biology \& Inflammatory Disorder Division, CSIR- Indian Institute of Chemical Biology, 4 \\ Raja S.C. Mullick Road, Kolkata, West Bengal, India. \\ 2.Department of Health Sciences, NSHM Knowledge Campus, 124(60), Basanta Lal Saha Road, Tara Park, Behala, Kolkata, India. \\ *Corresponding author's E-mail: shilabesra@iicb.res.in
}

Received: 09-08-2021; Revised: 24-10-2021; Accepted: 03-11-2021; Published on: 15-11-2021.

\begin{abstract}
Zinc Oxide $(\mathrm{ZnO})$ nanoparticle was synthesized using rhizome extracts of Zingiber officinale for in-vitro anti-cancer study. The characterization of nanoparticle was confirmed using ultraviolet spectroscopy and Fourier Transfer Infrared Spectroscopy (FTIR). The ZGNPE characterization also used the UV-Vis Spectrophotometer spectrum technique to measure the structural characterization of nanoparticles by determine the absorbance measurement. Cytotoxic activity of myelogenous leukemia cells (K562) and normal human embryonic Kidney (HEK293T) cells were performed by MTT assay. Treated with ZnO nanoparticle with Zingiber officinale extracts (ZGNPE) showed significant inhibition on the cancer cells whereas in normal cell showed insignificant toxicity. Thus, ZGNPE may be used as chemotherapy drug and an enormous medical application with less toxicity in future. Further mechanistic studies are in progress.
\end{abstract}

Keywords: Zinc Oxide Nanoparticles, Zingiber officinale, Cancer, Leukemia, Cytotoxicity.

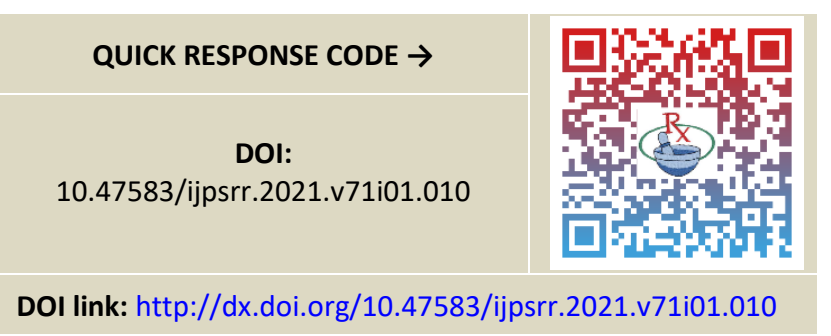

\section{INTRODUCTION}

$\mathrm{N}$ anoparticle represents a new platform to produce new novel cancer therapeutics. ${ }^{1}$ Nanomaterials attracted interest due to the unique physical and chemical properties, and they have been used for a broad range of biomedical applications. However, in the recent year's transition metal oxide nanoparticles having semiconductor properties like $\mathrm{ZnO}, \mathrm{CuO}, \mathrm{TiO}_{2}$ have attracted researchers to focus on their synthesis. Of these ZnO nanoparticle production has been concentrated more due to its diversifying properties which includes catalysis, electrical conductivity, antibacterial activity, cytotoxicity etc. Though there are several conventional physical and chemical methods available for their synthesis, biological method has attained a growing interest due to their advantages. The biological method of synthesizing metal oxide nanoparticles may be of three ways, which includes the use of microbes, plant or with enzymes. The use of plants or their extracts, for the synthesis of nanoparticles has been focused due to its simplicity, lower cost and also it involves proteins as capping or reducing agent. Zingiber officinale commonly known as ginger variety pharmacological properties of such as anti-inflammatory, analgesic, anti-oxidant, hepatoprotective, which is due to the presence of volatile oils like sesquiterpene alcohol, zingiberol and monoterpene. ${ }^{2}$ Over here Zingiber officinale extract was co-operated with $\mathrm{ZnO}$ nanoparticles in the form of precursor which will help to show the increase in cytotoxic activity. ${ }^{3}$ Cancer cells are normally highlyspecialized cells which have regressed to a much simpler, more primitive stage and which, unlike the normal parent, divide continuously, although inefficiently. ${ }^{4,5,6}$ The mechanisms by which nanoparticles exerts their toxic effects are not well known, but some recent studies attributed it to their greater surface, permeability into cells, and accumulate within cells and organisms, as well as, membrane damage, inflammation, DNA damage, apoptosis, and change in interactions between cells to cells and matrix. In recent years, zinc oxide has promoted itself as an interesting metal oxide material because of its unique physical and chemical properties such as high chemical and mechanical stability, broad range of radiation absorption, high catalysis activity, electro chemical coupling coefficient, non-toxic nature etc. ${ }^{7}$ Zinc oxide can be synthesized using many different methods including micro emulsion synthesis, spray drying, sol-gel method, pyrolysis, controlled precipitation, RF plasma synthesis, vapor transport process etc. controlled precipitation method was used here for the synthesis of zinc oxide nanoparticles. $^{8}$ In this study, we utilized zinc oxide nanoparticles using precursor of Zingiber officinale synthesized by Green synthesis method with the characterization of ZGNPE was done and we checked the effect of ZGNPE on leukemic cell line as well as on normal human embryonic kidney cell line. 


\section{MATERIALS AND METHODS}

\section{Chemicals and Reagents}

Zinc Sulphate Heptahydrate (LobaCheme Pvt. Ltd.), Sodium Hydroxide LR (MERCK), RPMI1640 medium with Lglutamine, D-MEM, HEPES (4-(2-hydroxyethyl)-1piperazineethanosulfonicc acid), Fetal bovine serum (FBS), Penicillin-Streptomycin, Gentamycin, MTT (3-(4,5dimethylthiazol-2-yl)-2,5-diphenyltertrazolium bromide), DMSO (dimethyl sulfoxide), Methanol, and the remaining chemicals and solvents were purchased from local firms and were of highest purity grade.

\section{Cell Culture}

K562 and HEK293T cells are purchased from National Centre of Cell Science, Pune. Human myelogenous leukemia cell line- K562 and human embryonic kidney (HEK293T) were used for in-vitro studies. The cells were sub-cultured as per the requirement of the experiment at an initial concentration of $1 \times 10^{6}$ cells $/ \mathrm{mL}$ and $\mathrm{K} 562$ maintained in sterile RPMI 1640 medium and HEK293T cells were sub-cultured using sterile D-MEM medium supplemented with $10 \%$ heat inactivated FBS. Cultures were maintained at $37^{\circ} \mathrm{C}$ in a humified atmosphere containing $5 \% \mathrm{CO}_{2}$ in air.

\section{Preparation of $\mathrm{ZnO}$ Solution}

Prepared different concentration like $0.25 \mathrm{M}, 0.5 \mathrm{M}$ and $1 \mathrm{M}$ of Zinc Sulphate Heptahydrate with weights taken like $3.59 \mathrm{gm}, 7.18 \mathrm{~g}$ and $14.37 \mathrm{gm}$. The solutions are dissolved in $100 \mathrm{~mL}$ distilled water. Kept over a magnetic stirrer and stayed for stirring almost for 10-15 min till clear solution comes. ${ }^{9,10}$

\section{Zingiber officinale extract preparation}

$2 \mathrm{~g}$ of ginger was weighed and grinded in a mortar pestle. Ginger should be grinded well and paste was made. In a beaker, $50 \mathrm{~mL}$ of distilled water was taken and the paste was poured on it. At 70 ㅇ C, it was kept for heating at least for $2 \mathrm{hrs}$ till the solution becomes yellow in colour. The yellow coloured solution was filtered with Whatman filter paper and the solution was kept in freeze at $4{ }^{\circ} \mathrm{C} .{ }^{11}$

\section{Green Synthesis- Preparation of ZGNPE}

Different concentrations of prepared ZGNPE were prepared. On the prepared Zinc solution, slowly ginger extracted solution was added and kept under constant stirring. The temperature was maintained at $70 \circ \mathrm{C}$ in a magnetic stirrer and kept for stirring for at least 2-3hrs by keeping a petri dish over it. Maintaining $\mathrm{pH}$ at $12, \mathrm{NaOH}$ was added in solution. After terminating the reaction, the pale yellow white ppt was then taken out and washed over and over again with distilled water followed by ethanol to get free of the impurities and then a pale-yellow powder of ZGNPE was obtained. The resulting powder was annealed at $400{ }^{\circ} \mathrm{C}$ for $2 \mathrm{hrs}^{1,12,13,14}$

\section{Characterization of ZGNPE}

ZGNPE characterized was done by UV spectroscopy and FTIR (Fourier Transfer Infrared Spectroscopy). In UV, the peak was found at $364 \mathrm{~nm}$. In FTIR, the absorption bands were found between $1500-1650 \mathrm{~cm}^{-1}$ for $\mathrm{C}=\mathrm{C}$ and $\mathrm{C}=\mathrm{N}$ and $2000-2500 \mathrm{~cm}^{-1}$ bands for alkynes. We confirmed that the carbonyl groups from the amino acids residues and proteins has the stronger ability to bind metal indicating that the proteins could possibly from the metal nanoparticles to prevent agglomeration and thereby stabilize the medium. This suggests that the biological molecules could possibly thereby stabilize the medium. This suggests that the biological molecules could possibly perform dual functions of formation and stabilization of ZGNPE. This interaction makes these NPs a perfect candidate for various applications such as drug delivery ${ }^{15}$ and study of biological interactions. ${ }^{16}$

\section{Cytotoxicity Study on K562 and HEK293T cell line}

For cytotoxicity analysis Human myelogenous leukemia cell line- K562 and human embryonic kidney (HEK293T), were seeded in 96 well tissue culture plates. They were separately treated with freshly prepared $1 \mathrm{mg} /$ $\mathrm{mL}$ stock solution of ZGNPE in various concentrations 25 , 50,100 and $200 \mu \mathrm{g} / \mathrm{ml}$ at 24, 48, 72hrs and incubated at $37^{\circ} \mathrm{C}$ in a humidified atmosphere containing $5 \% \mathrm{CO}_{2}$ in air. Untreated cells served as control. At the end of treatment, $20 \mu \mathrm{L}$ of MTT [3-(4,5- dimethylthiozol-2-il)-2,5-2,5dipheniltetrazoliumbromide] was added to each well and incubated for another $4 \mathrm{hrs}$ at $37^{\circ} \mathrm{C}$ in a $\mathrm{CO}_{2}$ incubator. The MTT assay is colorimetric assays for measuring the activity of enzymes that reduce MTT to formazan dyes, giving a purple colour. A solubilisation solution of DMSO $100 \mu \mathrm{L}$ is added in the insoluble purple formazan product into a coloured solution. The absorbance was taken at $492 \mathrm{~nm}$ for K562 cells and $570 \mathrm{~nm}$ for HEK293T cells by micro plate manager (Reader type- Model 680 XR Bio-Rad laboratories Inc.). The $I C_{50}$ values were noted for both the cells.

\section{Statistical Analysis}

Percentage of cell growth inhibition was calculated by the following formula: \% Cell Inhibition= $10 \times$ (O.D of Control - O.D. of treated/O. D. of Control), O. D=Optical Density. Percentage of cell viability was calculated as follows: Viable Cells $(\%)=($ Total number viable cells per $\mathrm{ml} /$ Total number of cells per $1 \mathrm{ml}) \times 100$.

\section{RESULTS}

\section{Zingiber officinale extract preparation}

When the solution of well grind ginger is heated at 70 ㅇ C, and the filtration is done with Whatman Filter Paper. The remaining solution was at $15-20 \mathrm{ml}$.

\section{Green Synthesis- Preparation of ZGNPE}

The total yield percentage of all remaining extractions are here tabulated below. Yield \%= Actual Yield/Theoretical Yield $x$ 100\%. 


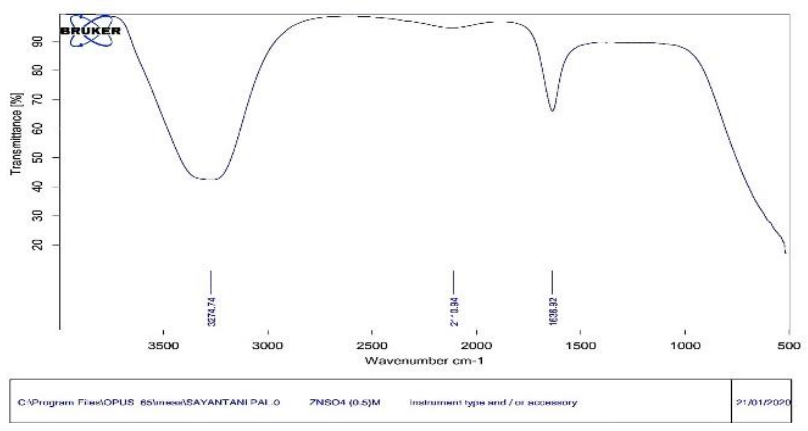

Figure 1: FTIR reading of ZGNPE concentration of $0.5 \mathrm{M}$. The absorption bands were found between $1500-1650$ $\mathrm{cm}^{-1}$ for $\mathrm{C}=\mathrm{C}$ and $\mathrm{C}=\mathrm{N}$ and $2000-2500 \mathrm{~cm}^{-1}$ bands for alkynes.

Table 1: indicate the \% of Yield samples and $\mathrm{pH}$ of samples solution was maintained in alkaline state.

\begin{tabular}{|c|c|c|c|}
\hline SAMPLES & $\begin{array}{c}\text { Weight } \\
\text { /gm }\end{array}$ & $\begin{array}{c}\text { Yield } \\
\text { samples /gm }\end{array}$ & Yield \% \\
\hline ZGNPE 1 & $3.59 \mathrm{gm}$ & 2.54 & $70.75 \%$ \\
\hline ZGNPE 2 & $3.59 \mathrm{gm}$ & 2.34 & $65.18 \%$ \\
\hline ZGNPE 3 & $3.59 \mathrm{gm}$ & 2.54 & $70.75 \%$ \\
\hline ZGNPE 4 & $7.18 \mathrm{gm}$ & 6.54 & $91.08 \%$ \\
\hline ZGNPE 5 & $7.18 \mathrm{gm}$ & 5.87 & $81.75 \%$ \\
\hline ZGNPE 6 & $7.18 \mathrm{gm}$ & 5.91 & $82.31 \%$ \\
\hline ZGNPE 7 & $7.18 \mathrm{gm}$ & 5.74 & $79.94 \%$ \\
\hline ZGNPE 8 & $14.37 \mathrm{gm}$ & 12.84 & $89.35 \%$ \\
\hline ZGNPE 9 & $14.37 \mathrm{gm}$ & 12.45 & $86.63 \%$ \\
\hline ZGNPE 10 & $14.37 \mathrm{gm}$ & 11.46 & $79.74 \%$ \\
\hline
\end{tabular}

\section{Identification and assay of Zn Salt}

It becomes yellow when strongly heated, the yellow colour disappears on cooling. As the indicator is poured in dropwise, the solution becomes yellow. $1 \mathrm{ml}$ of $0.1 \mathrm{M}$ disodium edetate equivalent to $0.008138 \mathrm{gm}$ of $\mathrm{ZnO}$.
Table 2: Indicate the pH of ZGNPE Samples

\begin{tabular}{|c|c|}
\hline SAMPLES & pH \\
\hline ZGNPE 1 & 12.41 \\
\hline ZGNPE 2 & 11.48 \\
\hline ZGNPE 3 & 11.25 \\
\hline ZGNPE 4 & 12.03 \\
\hline ZGNPE 5 & 12.01 \\
\hline ZGNPE 6 & 12.00 \\
\hline ZGNPE 7 & 12.08 \\
\hline ZGNPE 8 & 11.54 \\
\hline ZGNPE 9 & 11.67 \\
\hline ZGNPE 10 & 11.87 \\
\hline
\end{tabular}

\section{Fourier Transform Infrared Spectroscopy (FTIR)}

All the apprehensible functional groups involved in capping and reduction of $\mathrm{ZnO}$ NPs were identified using FTIR (Bruker V70). FTIR measurements were carried out to identify the biomolecules for capping and efficient stabilization of the metal nanoparticles synthesized. From the analysis of FTIR studies we confirmed that the carbonyl groups from the amino acids residues and proteins has the stronger ability to bind metal indicating that the proteins could possibly from the metal nanoparticles to prevent agglomeration and thereby stabilize the medium. This suggests that the biological molecules could possibly thereby stabilize the medium. This suggests that the biological molecules could possibly perform dual functions of formation and stabilization of ZNGPE. Fig 10. image of ZGNPE showed the peak at bands between $1500-1650$ $\mathrm{cm}^{-1}$ for $\mathrm{C}=\mathrm{C}$ and $\mathrm{C}=\mathrm{N}$ and $2000-2500 \mathrm{~cm}^{-1}$ bands for alkynes. For Fig 11, the peak at $451 \mathrm{~cm}^{-1}$ in the characteristic absorption of $\mathrm{Zn}-\mathrm{O}$ bond. Other absorption peaks while corresponding the carboxylate and hydroxyl impurities in the materials. Fig. 12, from ginger extract solution, the absorption bands are found peak between $1635-2121 \mathrm{~cm}^{-1}$. Aldehydes, ketones, carboxylic acids and esters were present between these bands.

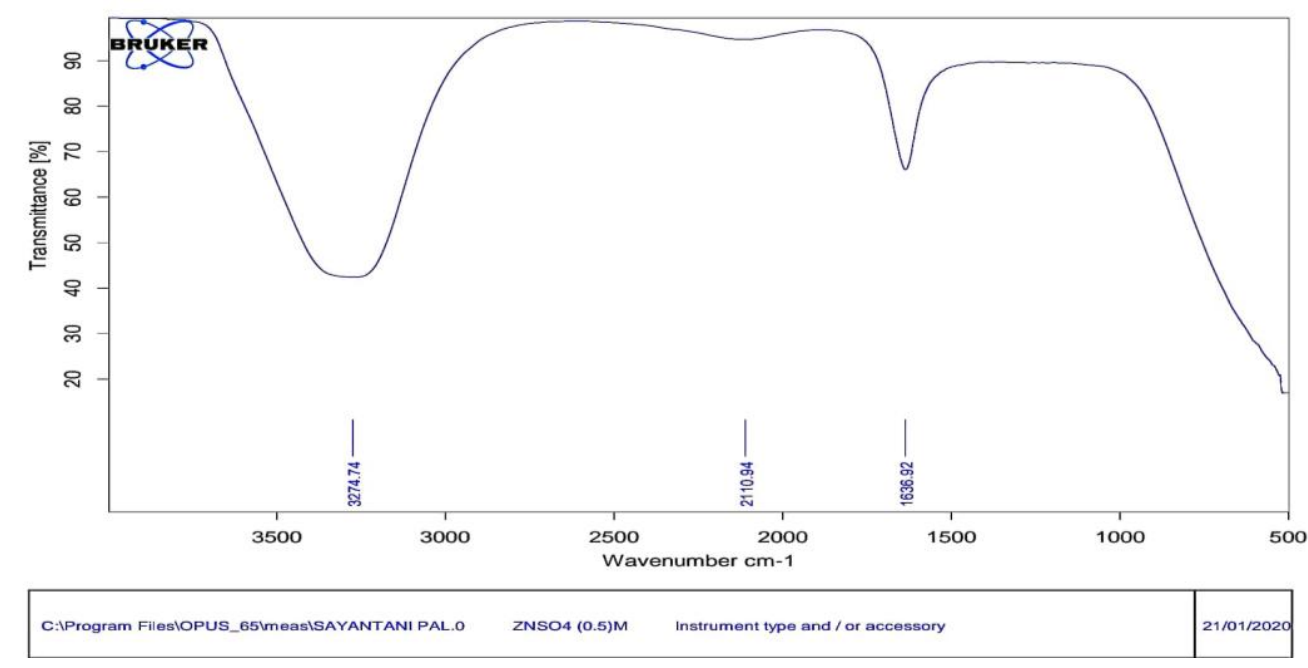

Figure 2: FTIR reading of $\mathrm{ZnO}$ powder. The peak at $451 \mathrm{~cm}^{-1}$ in the characteristic absorption of $\mathrm{Zn}-\mathrm{O}$ bond. 


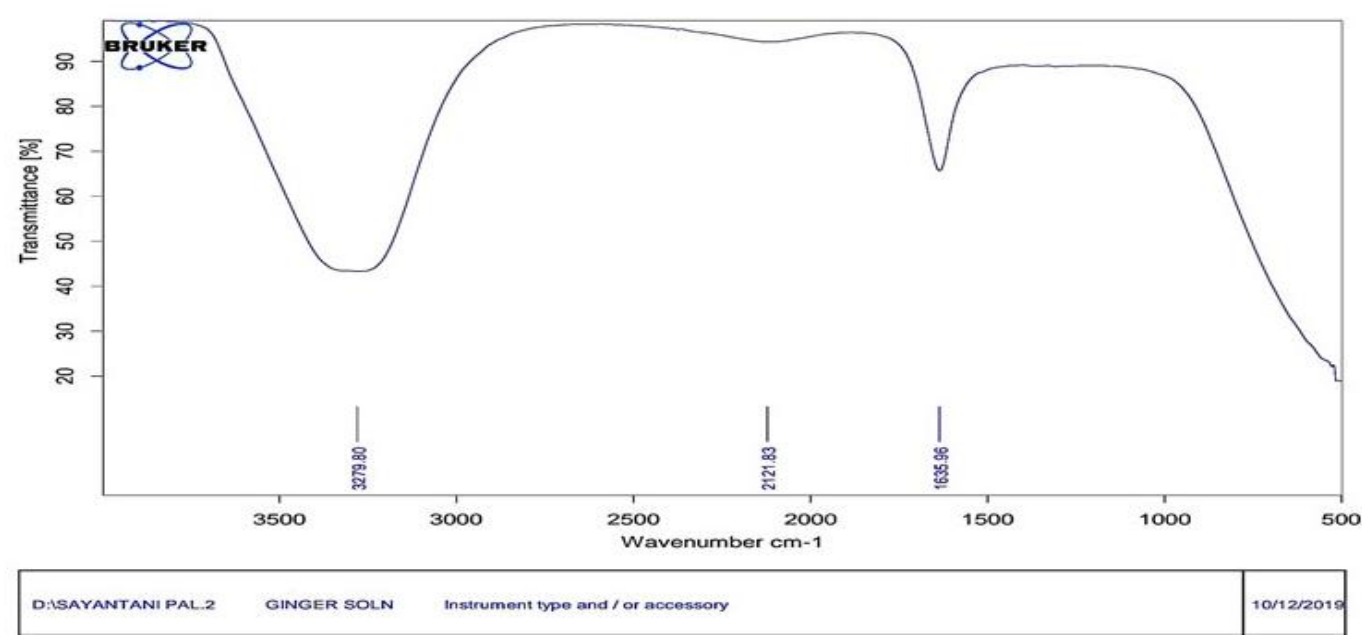

Figure 3: FTIR reading of Ginger extract. The absorption bands are found peak between $1635-2121 \mathrm{~cm}^{-1}$. Aldehydes, ketones, carboxylic acids and esters were present between these bands.

Cytotoxicity study on K562 \& HEK 293Tcell line by MTT Assay

ZGNPE inhibited the growth and produced significant cytotoxicity of myelogenous leukemia cell lines in a concentration-dependent manner. Reduction in the mean OD of cells treated with the increasing dose of ZGNPE was observed as compared to control. ZGNPE exerted 50\% growth inhibition $\left(\mathrm{IC}_{50}\right)$ of $\mathrm{K} 562$ cell line at concentration $25 \mu \mathrm{g}, 50 \mu \mathrm{g}, 100 \mu \mathrm{g}$ and $200 \mu \mathrm{g}$ for 24,48 and $72 \mathrm{hrs}$. The extract number two, five $\&$ six (ZGNPE) IC 50 values were shown under in the time at $24 \mathrm{hrs}$ and remaining extracts were found in 48 hrs. whereas ZGNPE produced insignificant cytotoxicity of human embryonic kidney cell line. ZGNPE exerted not above the $50 \%$ growth inhibition

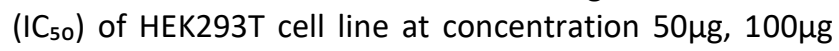

and $200 \mu \mathrm{g}$ for $24 \mathrm{hrs}$. Toxicity effect does not observe on this results so further checking was not done.

(TABLE- 3)

\begin{tabular}{|c|c|c|}
\hline SAMPLES & $\begin{array}{c}\text { Time taken to } \\
\text { reach 50\% }\end{array}$ & IC $_{\mathbf{5 0}}$ values \\
\hline ZGNPE 2 & $24 \mathrm{hrs}$ & $128.75 \mu \mathrm{g} / \mathrm{ml}$ \\
\hline ZGNPE 3 & $48 \mathrm{hrs}$ & $134.38 \mu \mathrm{g} / \mathrm{ml}$ \\
\hline ZGNPE 4 & $48 \mathrm{hrs}$ & $70.78 \mu \mathrm{g} / \mathrm{ml}$ \\
\hline ZGNPE 5 & $24 \mathrm{hrs}$ & $38.44 \mu \mathrm{g} / \mathrm{ml}$ \\
\hline ZGNPE 6 & $24 \mathrm{hrs}$ & $193.23 \mu \mathrm{g} / \mathrm{ml}$ \\
\hline ZGNPE 9 & $48 \mathrm{hrs}$ & $249.36 \mu \mathrm{g} / \mathrm{ml}$ \\
\hline ZGNPE 10 & $48 \mathrm{hrs}$ & $236.58 \mu \mathrm{g} / \mathrm{ml}$ \\
\hline
\end{tabular}

IC 50 Values of ZGNPE on K562 Cells for 24,48 and $72 \mathrm{hrs}$
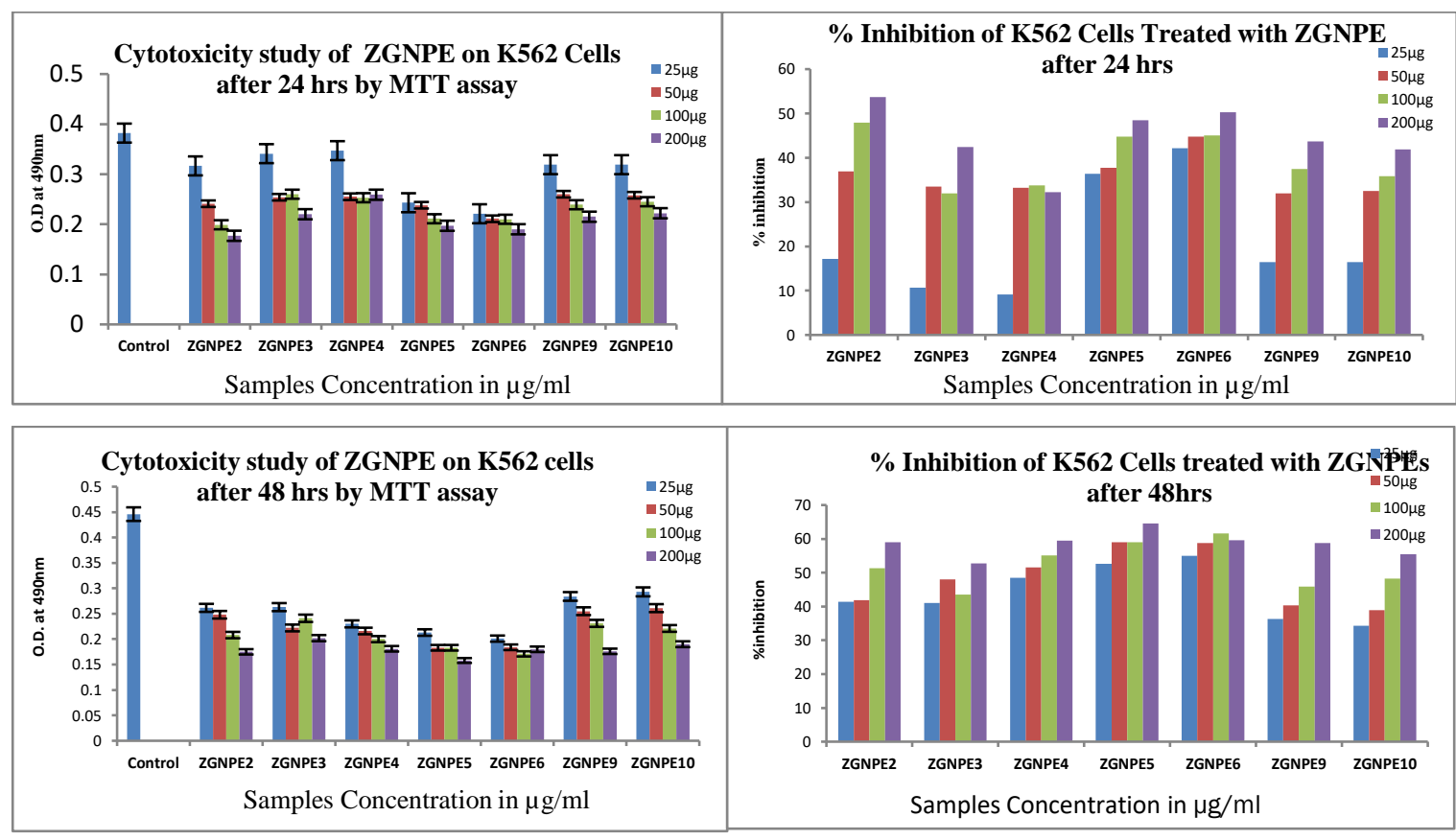

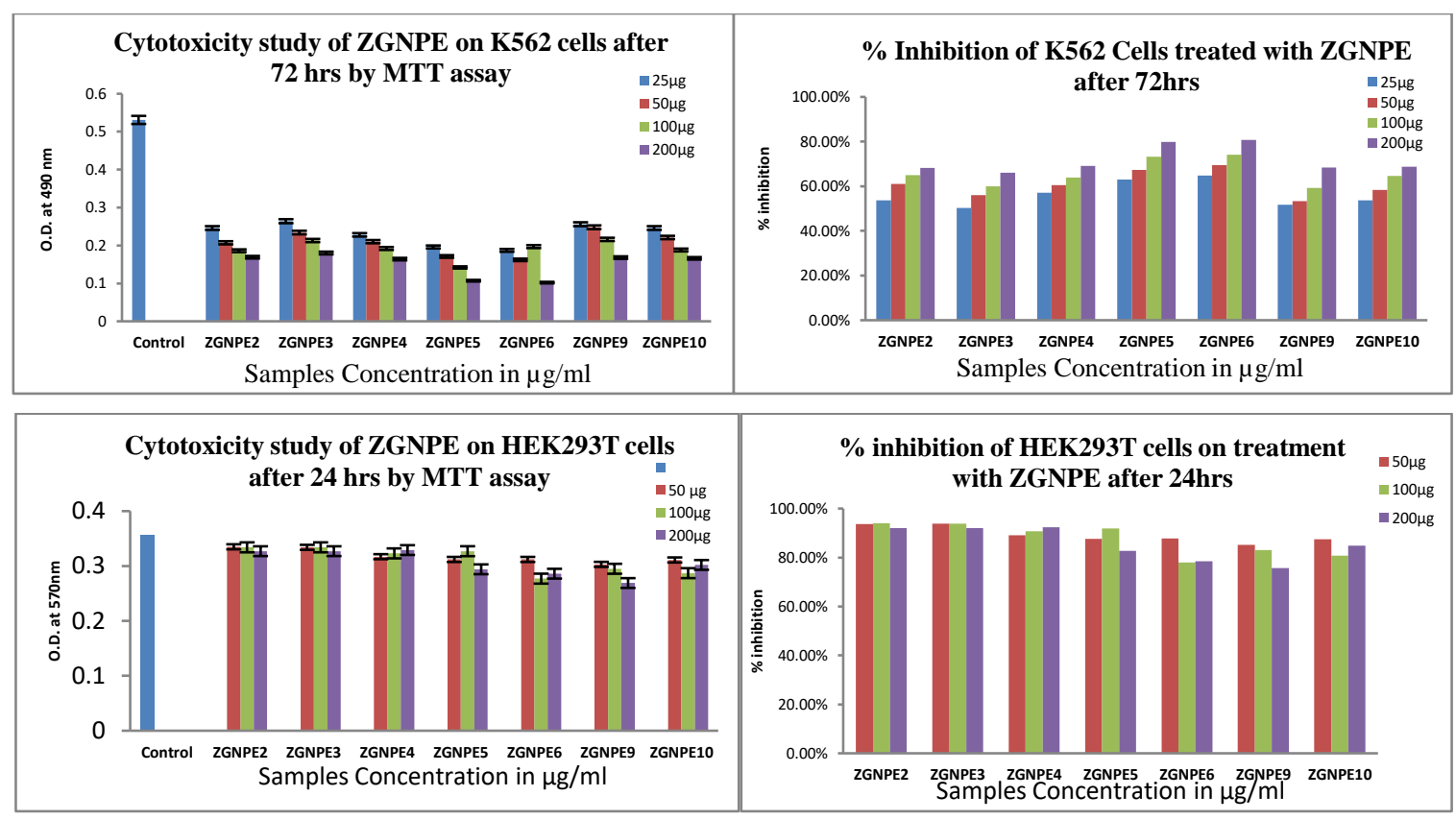

Figure 4: Histograms showed the OD value and \% of inhibition in K562 and Hek293T cells after 24,48 and 72hrs of treatment with ZGNPE respectively. The change in O.D. value at $492 \mathrm{~nm}$ for $\mathrm{K} 562$ and $570 \mathrm{~nm}$ for Hek293T cells was observed against different samples. Histogram showed significant Inhibition in O.D value in K562 cells whereas no change in Hek293T cells treated with ZGNPE. The \% inhibition was calculated from the O.D. value. Data are mean \pm S.E.M.

\section{DISCUSSION}

Green synthesized zinc oxide nanoparticles appear in different shapes such as nano-powder or nano-cluster or nano-crystal the plant extract phenol compounds it may be effect on size and shapes. ${ }^{17}$ Green synthesized $\mathrm{ZnO}$ is an environmentally eco-friendly material, which is desirable especially for bio-applications, such as seed germination, bio-imaging and cancer detection. The use of zinc oxide nanoparticles is increasing in agricultural products and consumer goods, as well as several research works related to development of anti-cancer nanoparticulate dosage form. These type of application of biosynthesized ZGNPE have been under current research scenario by several workers. ${ }^{18}$ which prompts the present research initiative. ${ }^{19}$ ZGNPE was synthesized using rhizome extracts of Zingiber officinale for in-vitro anti-cancer study supporting the latest findings of other biosynthesized zinc oxide nanoparticles for in-vitro cancer evaluations. Identification of zinc oxide has been done where results were shown zinc metal is present. Zinc oxide has been identified through pharmacopeial method of analysis (IP-2011, Vol- III, pg2336) indicating the formation of ZGNPE. The ZGNPE characterization also used the UV-Vis spectrum and FTIR technique to assess the structural characterization of nanoparticles. The UV-Vis spectra of synthesized nanoparticles were recorded on Shimadzu UV-1601 at $364 \mathrm{~nm}$ operated at a resolution of $20 \mathrm{~nm}$. Through FTIR the presence of zinc is confirmed through wave numbers between $500-2500 \mathrm{~cm}-1.20$ These functional groups identify the formation of zinc oxide nanoparticles in the similar way as other researchers characterized the similar formation of biosynthesized ZGNPE as the functional groups associated with the ZGNPE formation having spectral peaks at $683-500 \mathrm{~cm}-1$ and $698-505 \mathrm{~cm}-1$ which proposed the formation of $\mathrm{ZnO}$ nanoparticles in Zingiber officinale extracts. ${ }^{21}$ ZGNPE concentration of $0.5 \mathrm{M}$ showed the peak at bands between $1500-1650 \mathrm{~cm}^{-1}$ for $\mathrm{C}=\mathrm{C}$ and $\mathrm{C}=\mathrm{N}$ and $2000-2500 \mathrm{~cm}^{-1}$ bands for alkynes. For Zinc oxide $\mathrm{KBr}$ compressed pellets and found at the peak at $451 \mathrm{~cm}^{-1}$ in the characteristic absorption of $\mathrm{Zn}-\mathrm{O}$ bond. ${ }^{22}$ Other absorption peaks while corresponding the carboxylate and hydroxyl impurities in the materials. Aldehydes, ketones, carboxylic acids and esters were present between these bands. ${ }^{23}$ From ginger extract solution, the absorption bands are found peak between $1635-2121 \mathrm{~cm}^{-1} .{ }^{24}$ FTIR spectra affirm successful capping of biomolecules on the NP surface and thus provide stability and dispersion capacity to ZnO-NPs in aqueous media. Several studies have suggested an increase in in vitro cytotoxicity with nanophase $\mathrm{ZnO}$ compared with micrometer sized $\mathrm{ZnO}$ for several types of cancer, including glioma, breast, bone, colon, and leukemias and lymphoma. ${ }^{25}$ Cytotoxic activities was performed with varying concentrations $(25 \mu \mathrm{g} / \mathrm{ml}, 50$ $\mu \mathrm{g} / \mathrm{ml}, 100 \mu \mathrm{g} / \mathrm{ml}, 200 \mu \mathrm{g} / \mathrm{ml}$ ) against cell line like myelogenous leukemia cell line (K562) and on normal human embryonic kidney cell line (HEK293T) cells. In K562 cells showed best on ZGNPE. A number of other researchers have noticed that Zinc oxide nanoparticles are cytotoxic only to cancerous cells and do not have any toxic effects on normal cell lines. ${ }^{26,27}$ However, the cytotoxicity of some chemical synthesized nanoparticles has been confirmed on normal cells even at lower concentration in comparison of cancer cell lines; for this reason, green synthesis of nanoparticles becomes more attractive as an alternative method due to the decreasing bio toxicity effects of nanoparticles, through the use of non-noxious components instead of chemicals agent over the last 
recent years. ${ }^{28}$ And also reported morphological changes induced by cytotoxic ZGNPEs on different cell lines. Morphological changes in cells may affect their metastatic process including substrate attachment, migration and invasion. ${ }^{29}$ On HEK293T cells, showed minimal toxic effect on applying various concentrations $(25 \mu \mathrm{g} / \mathrm{ml}, 50 \mu \mathrm{g} / \mathrm{ml}$, $100 \mu \mathrm{g} / \mathrm{ml}, 200 \mu \mathrm{g} / \mathrm{ml}$ ) at 24hrs. The cytotoxic activity yielded inhibition of concentration at $38.44 \mu \mathrm{g} / \mathrm{ml}$ at $48 \mathrm{hrs}$ on $\mathrm{K} 562$ cell line. The cytotoxic activity yielded inhibition of concentration at $39.83 \mu \mathrm{g} / \mathrm{ml}$. Based on enhanced biocompatibility, improved solubility and less toxicity, the efficacy of ZGNPEs synthesized from Zingiber officinale in the field of medicine could play a significant role in future. In the light of current research, ZGNPEs could be developed as a potential next generation cancer treatment strategy. In order to do so, further research must be carried out in order to resolve the issue of cancer, a longterm health hazard.

\section{CONCLUSION}

The present study dealt with the biosynthesis of ZGNPE using the root extracts of Zingiber officinale that were characterized using UV Visible spectroscopy and FTIR. These results reveal that the nanoparticle were spherical in shape and had an average size. In UV, peak was found at range of $364 \mathrm{~nm}$. FTIR bands were shown through FTIR it is confirmed that zinc metal is present where wavelength is shown at $500-2500 \mathrm{~cm}^{-1}$. ZGNPE concentration of $0.5 \mathrm{M}$ showed the peak at bands between $1500-1650 \mathrm{~cm}^{-1}$ for $\mathrm{C}=\mathrm{C}$ and $\mathrm{C}=\mathrm{N}$ and $2000-2500 \mathrm{~cm}^{-1}$ bands for alkynes. For Zinc oxide solution where compressed with $\mathrm{KBr}$ pellets and found at the peak at $451 \mathrm{~cm}^{-1}$ in the characteristic absorption of $\mathrm{Zn}-\mathrm{O}$ bond. Other absorption peaks while corresponding the carboxylate and hydroxyl impurities in the materials. From ginger extract solution, the absorption bands are found peak between $1635-2121 \mathrm{~cm}^{-1}$. Aldehydes, ketones, carboxylic acids and esters were present between these bands. The synthesized ZGNPE were checked for cytotoxic activity on K562 and HEK293T cells which showed some desirable results on which we could conclude that sample on various concentrations are achieved with our motives. Moreover, the size of the nanoparticle also influenced the nanoparticle's cytotoxic activity. The ZGNPE shows higher activity against K562 cell line. The $\%$ inhibition almost showed $50 \%$ with in $24 \mathrm{hrs}$. In HEK293T cell line, there was no toxic nature found for the samples. Thus, we can say it is non-toxic in nature. ZGNPE are highly cytotoxic to $\mathrm{K} 562$ cells and the solubilization of $\mathrm{ZnO}$ is the main toxicological mechanism. Thus, by using the greener method for producing Zinc Oxide Ginger Nanoparticle Extracts (ZGNPE) can have a potential activity on treating ailments pertaining to cytotoxicity and hence further study in this regard is required to establish if beneficial effects in human being.

Acknowledgement: The authors of this paper are very much thankful to Council of Scientific and Industrial Research, Indian Institute of Chemical Biology(CSIR-IICB), Kolkata and NSHM Knowledge Campus, Kolkata (Group of
Institutions) for providing the funding to perform the research work.

\section{REFERENCES}

1. SINGH C, SHARMA V, NAIK PK, KHANDELWAL V, SINGH H, A Green biogenic approach for synthesis of gold and silver nanoparticles using Zingiber officinale, Digest Journal of Nanomaterials and Biostructures, 2011; 6: 535-542.

2. Banerjee S, Mullick $\mathrm{HI}$, Banerjee J, Development and characterization of metal oxide nanoparticles for the delivery of anticancer drug, Artificial cells nanomedicine and biotechnology, 2016; 44(2): 672-679.

3. Chandan S, Vineet S, Pradeep KRN, Vikas K, Harvinder, Silver nanoparticles using Ocimum sanctum (Tulsi) leaf extract and screening its antimicrobial activity. Journal of Nanoparticle Research, 2011 Jul; 13(7): 2981-8.

4. Singh RP, Magesh S, Rakkiyappan C. Ginger (Zingiber officinale) root Natural Gold. International Journal of Pharma and Biosciences, 2011; 2: 283-294.

5. Walton J.R. and Buckley I.K., Cell models in the study of mechanism of toxicity, Agents and Actions, 1975; 5: 69-88.

6. Singhal G, Bhavesh R, Kasariya K, Sharma AR, Singh RP, Biosynthesis extract: a source of silver nanoparticles and their application. Int. J. Bio-Eng. Sci. Technol., 2011; 2(3): 7580 .

7. Arakha M, Roy J, Nayak PS, Mallick B, Jha S, Zinc oxide nanoparticle energy band gap reduction triggers then oxidative stress resulting into autophagy-mediated apoptotic cell death, Free Radical Biology and Medicine, 2017; 110: 42-53.

8. Zhang J, Qin X, Wang B, et al., Zinc oxide nanoparticles harness autophagy to induce cell death in lung epithelial cells, Cell Death and Disease, 2017; 8(7): 29-54.

9. Kuppusamy, P., Yusoff, M. M., Maniam, G. P., \& Govindan, N., Biosynthesis of metallic nanoparticles using plant derivatives and their new avenues in pharmacological applications - An updated report. Saudi Pharmaceutical Journal, 2016; 24(4): 473-484.

10. Zhao X, Zhu H, Chen J, Ao Q. FTIR, XRD and SEM analysis of ginger powders with different size. Journal of Food Processing and Preservation, 2015; 39(6): 2017-26.

11. Xie $Y, H e ~ Y$, Irwin PL, Jin $T$, Shi $X$. Antibacterial activity and mechanism of action of zinc oxide nanoparticles against Campylobacter jejuni. Applied and environmental microbiology. 2011 Apr 1; 77(7): 2325-31.

12. Salam HA, Sivaraj R, Venckatesh R. Green synthesis and characterization of zinc oxide nanoparticles from Ocimum basilicum L. var. purpurascens Benth. -Lamiaceae leaf extract. Materials letters, 2014; 131: 16-8.

13. Kołodziejczak-Radzimska A, Jesionowski T. Zinc oxide-from synthesis to application: a review. Materials, 2014 Apr; 7(4): 2833-81.

14. Sangeetha G, Rajeshwari S, Venckatesh R. Green synthesis of zinc oxide nanoparticles by aloe barbadensis miller leaf extract: Structure and optical properties. Materials Research Bulletin, 2011; 46(12): 2560-6. 
15. Wang R, Billone PS, Mullett WM. Nanomedicine in action: an overview of cancer nanomedicine on the market and in clinical trials, Journal of Nanomaterials, 2013; Jan 1; 2013.

16. Song JY, Jang HK, Kim BS. Biological synthesis of gold nanoparticles using Magnolia kobus and Diopyros kaki leaf extracts, Process Biochemistry, 2009; 44(10): 1133-8.

17. Vadlapudi V, Kaladhar DS. Review: green synthesis of silver and gold nanoparticles. Middle-East Journal of Scientific Research, 2014; 19(6): 834-42.

18. Tsan L, Hon MH, Teoh IG, Structure and optical properties of $\mathrm{CeO} 2$ nanoparticles synthesized by precipitation, Journal of Electronic Materials, 2013; 42: 2536-2541.

19. Mirzaei H, Darroudi M. Zinc oxide nanoparticles: Biological synthesis and biomedical applications. Ceramics International. 2017 Jan 1; 43(1): 907-14.

20. Espitia PJ, Soares ND, dos Reis Coimbra JS, de Andrade NJ, Cruz RS, Medeiros EA, Zinc oxide nanoparticles: synthesis, antimicrobial activity and food packaging applications, Food and bioprocess technology, $2012 \mathrm{Jul}$; 5(5): 1447-64.

21. Singh RP, Shukla VK, Yadav RS, Sharma PK, Singh PK, Pandey AC, Biological approach of zinc oxide nanoparticles formation and its characterization, Adv. Mater. Lett. 2011 Oct $1 ; 2(4): 313-7$.

22. Subhankari I, Nayak PL, Antimicrobial activity of copper nanoparticles synthesized by ginger (Zingiber officinale) extract, World Journal of Nano Science \& Technology, 2013; 2(1): 10-3.
23. Priyaa GH, Satyan KB. Biological synthesis of silver nanoparticles using ginger (Zingiber officinale) extract, J Environ Nanotechnol., 2014; 3: 32-40.

24. Vijayalakshmi U, Chellappa M, Anjaneyulu U, Manivasagam G, Sethu S, Influence of coating parameter and sintering atmosphere on the corrosion resistance behavior of electrophoretically deposited composite coatings, Materials and Manufacturing Processes, 2016 Jan 2; 31(1): 95-106.

25. Jamdagni $P$, Khatri $P$, Rana JS. Green synthesis of zinc oxide nanoparticles using flower extract of Nyctanthes arbortristis and their antifungal activity, Journal of King Saud University-Science, 2018 Apr 1; 30(2): 168-75.

26. Akhtar MJ, Ahamed M, Kumar S, Khan MM, Ahmad J, Alrokayan SA, Zinc oxide nanoparticles selectively induce apoptosis in human cancer cells through reactive oxygen species, International journal of nanomedicine, 2012; 7: 845 .

27. Taccola L, Raffa V, Riggio C, Vittorio O, lorio MC, Vanacore R, Pietrabissa A, Cuschieri A, Zinc oxide nanoparticles as selective killers of proliferating cells, International journal of nanomedicine, 2011; 6: 1129.

28. Najim N, Rusdi R, Hamzah AS, Shaameri Z, Mat Zain M, Kamarulzaman N, Effects of the absorption behavior of ZnO nanoparticles on cytotoxicity measurements, Journal of Nanomaterials, 2014 Jan 1; 2014.

29. Brandhagen BN, Tieszen CR, Ulmer TM, Tracy MS, Goyeneche AA, Telleria CM, Cytostasis and morphological changes induced by mifepristone in human metastatic cancer cells involve cytoskeletal filamentous actin reorganization and impairment of cell adhesion dynamics, BMC Cancer, 2013 Dec; 13(1): 1-5.

Source of Support: The author(s) received no financial support for the research, authorship, and/or publication of this article.

Conflict of Interest: The author(s) declared no potential conflicts of interest with respect to the research, authorship, and/or publication of this article.

For any question relates to this article, please reach us at: editor@globalresearchonline.net New manuscripts for publication can be submitted at: submit@globalresearchonline.net and submit_ijpsrr@rediffmail.com 